UDK 341.485(591)

341.645 .2

Biblid 0543-3657, 71 (2020)

God. LXXI, br. 1179-80, str. 156-177

izvorni naučni rad

Primljen: 31.8.20200.

doi: https://doi.org/10.18485/iipe_mp.2020.71.1179_80.8

\author{
Marko NOVAKOVIĆ, Jovana BLEŠIĆ1
}

\title{
Okolnosti i specifičnosti postupka za genocid Mjanmara nad Rohindžama pred Međunarodnim sudom pravde
}

\author{
SAŽETAK
}

Genocid, kao zločin posebne težine i značaja, s pravom izaziva posebnu pažnju i oprez u pravnom životu. Kada je u pitanju njegovo procesuiranje na međunarodnopravnom terenu, Međunarodni sud pravde (MSP) je jedina relevantna adresa, a čak i u poslovičnoj interesantnoj i diskutabilnoj praksi MSP genocid zauzima posebno mesto. Upravo zato autori će analizirati progres koji je u slučaju Mjanmar napravljen pred MSP, ali će istovremeno predstaviti osnovne aspekte pojma genocida, a posebno specifičnosti samog slučaja koji bacaju posebno svetlo na celokupni proces.

Ključne reči: Mjanmar, Gambija, Rohindža muslimani, genocid, Međunarodni sud pravde.

\section{Uvodna razmatranja o Mjanmaru}

Mjanmar je zemlja koja se nalazi na jugoistoku Azije. Graniči se sa Indijom, Bangladešom, Tajlandom, Laosom i Kinom. Mjanmar, ranije Burma, jeste država u kojoj većinski živi budističko stanovništvo. Postoji 135

${ }^{1}$ Marko Novaković, naučni saradnik, Institut za međunarodnu politiku i privredu, Beograd. E-pošta: marko@diplomacy.bg.ac.rs

Jovana Blešić, istraživač-pripravnik, Institut za međunarodnu politiku i privredu, Beograd. E-pošta: jovana.blesic@diplomacy.bg.ac.rs

Rad je nastao u okviru naučnoistraživačkog projekta „Srbija i izazovi u međunarodnim odnosima 2020. godine”, koji finansira Ministarstvo prosvete, nauke i tehnološkog razvoja Republike Srbije, a realizuje Institut za međunarodnu politiku i privredu tokom

156 2020. godine. 
različitih etničkih grupa. ${ }^{2}$ Porast kulturnih i etničkih različitosti Mjanmara datira od kolonizacije koju su izvršili Britanci 1886. godine. Nakon Drugog svetskog rata, Ong San, lider komunističke partije pregovarao je i izvojevao nezavisnost od britanske krune 1947. godine, a zvanično 1949. godine Burma postaje nezavisna država. ${ }^{3}$

Muslimani su u Mjanmaru manjina. Konkretno, Rohindža muslimani žive u provinciji Rakajn. Rohindža muslimana ima oko dva miliona, sunitski su muslimani koji govore posebnim dijalektom i pišu na arapskom. Oni žive $\mathrm{u}$ tom delu Mjanmara još od VII veka, dok neki tvrde da je to od 1430-ih godina. U ranoj istoriji, Arakan je bila jedina muslimanska enklava u Burmi. ${ }^{4}$

Neprijateljstva prema Rohindža muslimanima datiraju još od ratova između Arakanskog kraljevstva i Burmanskog kraljevstva u XVIII i XIX veku. Nakon toga, Burma pada pod vlast Velike Britanije. Usledilo je vreme migracija i razvijanje identiteta koje se nije zasnivalo na pripadnosti određenom narodu. Tek nakon pada moći Britanskog kraljevstva u ovom delu sveta dolazi do stvaranja novih država i usvajanja zapadnih vrednosti koje identitet baziraju na pripadnosti određenom narodu. Etničke Rohindže su se mogle naći sa obe strane granice Burme i Bangladeša. ${ }^{5}$ Rohindže su bile prepoznate kao domorodačko stanovništvo sve do 1962. godine. Sa dolaskom vojne hunte na vlast, počinje i period oduzimanja političkih prava pripadnicima ove zajednice.

U novembru 2019. godine Gambija je podnela tužbu pred Međunarodnim sudom pravde protiv Mjanmara koja se odnosi na primenu Konvencije o sprečavanju i kažnjavanju zločina genocida. Gambija je ocenila da Međunarodni sud pravde ima ulogu čuvara Konvencije o sprečavanju i kažnjavanju zločina genocida, a pošto ne postoji adekvatan međunarodni krivični tribunal, niti konkretan pojedinac protiv kojeg bi se vodio postupak, odlučeno je da se postupak pokrene baš pred ovim sudom. ${ }^{6}$

${ }^{2}$ Ziaur Rahman, Jhensanam Anusara, Bousaone Chanthamith, Saddam Hossain, Al Amin, "Rohingya crisis: identity of Rohingya Muslim in Myanmar", International Research Journal of Social Sciences, Vol 7 (12), 12-16, 2018, p. 12.

${ }^{3}$ Abigail Knudson, "The Rohingya Refugee Crisis \& International Implications", 2020, pp. 2-3.

${ }^{4}$ Wendell Glenn P. Cagape, "Finding Foucault in the Rohingya Discourses", Aseannale, Capturing the spirit of Asean in the Digital Times, 2018, p. 6.

${ }^{5}$ Matteo Fumagalli, "Myanmar 2019: The lady and the generaux" in Asia in 2019: Escalating international tensions and authoritarian involution, Michelguglielmo Torri, Nicola Mocci and Filippo Boni (eds), Asia Maior, The Journal of the Italian Think Tank, 2020, Viella s.r.l. \& Associazione Asia Maior, pp. 313-314.

${ }^{6}$ International Court of Justice, Application instituting proceedings and request for provisional measures, Republic of the Gambia v. Republic of the Union of Myanmar, 11 November 2019, para. 5. 


\section{Pojam genocida}

Razmatranje koncepta genocida, kao zločina sui generis, izazvali su zločini koje su tokom Drugog svetskog rata činili pripadnici nacističke ideologije. Tvorac pojma genocida je Rafael Lemkin, koji je ovaj termin iskoristio 1942. godine, između ostalog i u sklopu svojih diplomatskih napora da ubedi Sjedinjene Američke Države da intervenišu po pitanju zločina nad Jeverjima od strane nacističke Nemačke, mada se ovaj termin pojavljuje prvi put za širu javnost u njegovoj knjizi "Axis Rule in Occupied Europe" objavljenoj 1944. godine. ${ }^{7} \mathrm{U}$ ovom radu autori će analizarati tužbu Gambije protiv Mjanmara pred Međunarodnim sudom pravde vezanu za kršenje Konvencije o sprečavanju i kažnjavanju zločina genocida. Gambija tvrdi da Mjanmar sprovodi genocid nad Rohindžama, muslimanskom manjinom u toj državi.

Konvencija o sprečavanju i kažnjavanju zločina genocida najznačajniji je dokument koji se bavi ovim pitanjem i u njoj je definisan pojam genocida, koji do tada nije imao opšteprihvaćeno značenje. Konvencija je doneta u tri koraka. Prvo je Sekretarijat Ujedinjenih nacija doneo nacrt teksta, koji je sačinjen uz pomoć tri eksperta - jedan od njih bio je upravo Lemkin, uz istaknutog rumunskog pravnika Vespasijana Pele i Anrija Donedjua de Fabra, francuskog pravnika i sudije na Nirnberškim suđenjima. Zatim je taj nacrt dokumenta dodatno doradio ad hoc Komitet, formiran od strane Ekonomskog i socijalnog saveta, $\mathrm{i}$ onda je dat na formalno usvajanje Generalnoj skuštini Ujedinjenih nacija 1948. godine. Ova konvencija definiše genocid u članu dva na sledeći način: „U smislu ove Konvencije kao genocid se smatra bilo koje od navedenih dela učinjenih u nameri potpunog ili delimičnog uništenja jedne nacionalne, etničke, rasne ili verske grupe kao takve: a) ubistvo članova grupe; b) teška povreda fizičkog ili mentalnog integriteta članova grupe; c) namerno podvrgavanje grupe životnim uslovima koji treba da dovedu do njenog potpunog ili delimičnog uništenja; d) mere uperene na sprečavanje rađanja u okviru grupe; e) prinudno premeštanje dece iz jedne grupe u drugu. ${ }^{\prime 8} \mathrm{U}$ jednom od nacrta Konvencije bila je predložena podela genocida na fizički, biološki i kulturni, ali se od toga u samoj Konvenciji odustalo. ${ }^{9}$

\footnotetext{
${ }^{7}$ Douglas Irvin-Erickson, Raphael Lemkin and the Concept of Genocide, University of Pennsylvania Press, 2017, p. 138.

${ }^{8}$ Član 2 Konvencije o sprečavanju i kažnjavanju zločina genocida.

${ }^{9}$ William A. Schabas, "Convention on Prevention and Punishment of the Crime of Genocide", Audiovisual Library on International Law, dostupno na https:/ / legal.un.

$158 \mathrm{org} / \mathrm{avl} / \mathrm{ha} / \mathrm{cppcg} / \mathrm{cppcg} . \mathrm{html}$, datum pristupa 21/08/2020.
} 
Univerzalna nadležnost u međunarodnom pravu predstavlja ideju da nacionalni sudovi mogu da gone pojedince za najteža međunarodna krivična dela, te samim tim i za genocid na osnovu toga da takva krivična dela štete celoj međunarodnoj zajednici. Po pravilu se ova nadležnost primenjuje onda kada nijedan drugi osnov (personalni, teritorijalni ili pasivni personalni) ne može da se primeni. ${ }^{10}$ Još je Lemkin postavio okvire univerzalne nadležnosti kroz ono što se naziva obaveza gonjenja ili izručenja. To znači da država u kojoj je osumnjičeni bio prisutan mora ili da počne postupak protiv njega ili da ga izruči drugoj državi u kojoj će mu biti suđeno. U početku je smisao primene univerzalne nadležnosti bio da se spreči da zločinac slobodno živi u drugoj državi. Ipak, istorijat stvaranja nacrta Konvencije o sprečavanju i kažnjavanju zločina genocida, pokazuje nam da je primena univerzalne nadležnosti na ovo krivično delo namerno izostavljena iz samog teksta. Naime, u prvobitnom nacrtu postojala je odredba o univerzalnosti, međutim, tokom diskusija, iz straha da će biti povređen suverenitet države, odredba je izbačena. ${ }^{11}$ Upravo po tom osnovu, u novembru 2019. godine, Rohindža organizacije (Burmese Rohingya Organisation UK - BROUK), kao i organizacije iz država Latinske Amerike koje se bave ljudskim pravima, podnele su tužbu u Argentini. Tuženi su politički i vojni lideri Mjanmara, između ostalog, šef vojske Min Aung Hlang i civilni vođa Ong San Su Đi za dovođenje Rohindži u egzistencijalnu pretnju. ${ }^{12}$ Dan nakon toga, Pretresno veće Međunarodnog krivičnog suda odobrilo je istragu o situaciji u Rakajnu. Mjanmar nije potpisnica Rimskog statuta, pa zato Međunarodni krivični sud ne može da zasnuje nadležnost na toj teritoriji, ali može na teritoriji Bangladeša gde se nalazi veliki broj izbeglica. ${ }^{13}$

Genocid u Mjanmaru nije samo primer primene univerzalne nadležnosti, već i primene člana 9 Konvencije o sprečavanju i kažnjavanju zločina

${ }^{10}$ Universal Jurisdiction, International Justice Resource Center, dostupno na https:/ / ijrcenter.org/cases-before-national-courts/domestic-exercise-of-universaljurisdiction/, datum pristupa 21/08/2020.

${ }^{11}$ Amina Adanan, "Symposium on the Genocide Convenction: Reflecting on the Genocide Convention at 70: How genocide became a crime subject to universal jurisdiction", EJIL: Talk" Blog of the European Journal of International Law, 16 Maj 2019, https://www.ejil talk.org/symposium-on-the-genocide-convention-reflecting-on-the-genocideconvention-at-70-how-genocide-became-a-crime-subject-to-universal-jurisdiction/.

12 "Aung San Suu Kyi named in Argentine lawsuit over crimes against Rohingya", Bangkok Post, 14 Novembar 2019, https:/ /www.bangkokpost.com/world/1793549/ aung-san-suu-kyi-named-in-argentine-lawsuit-over-crimes-against-rohingya.

${ }^{13}$ Marta Bo, "Crimes against the Rohingya: ICC Jurisdiction, Universal Jurisdiction in Argentina, and the Principle of Complementarity", http:/ / opiniojuris.org/2019/12/ 23/crimes-against-the-rohingya-icc-jurisdiction-universal-jurisdiction-in-argentinaand-the-principle-of-complementarity/, 07/08/2020. 
genocida. U članu 9 Konvencije, eksplicitno se navodi nadležost Međunarodnog suda pravde kada je u pitanju genocid. ${ }^{14}$ Upravo zato, od krucijalnog začaja za razumevanje pravnog pojma genocida jeste praksa Međunarodnog suda pravde, jer je on najpozvaniji i jedini organ kome je data mogućnost da daje odgovore na nedoumice povodom tumačenja ovog pojma. Još jedan razlog je da je, za razliku od mnogih drugih pitanja kako u pravu tako i u ostalim oblastima čovekovog delovanja, poznavanje i prihvatanje jedne definicije genocida izuzetno važno da bi se izbegle potencijalne manipulacije i zloupotrebe za političke i ostale populističke potrebe koje su česte, i za šta najozbiljniji zločini poput ovog često služe a koji se ne bi smeli ni na koji način zloupotrebljavati.

\section{Položaj Rohindža muslimana u Mjanmaru}

Ako uzmemo da su osnovna ljudska prava proklamovana međunarodnim konvencijama poput Univerzalne deklaracije o ljudskim pravima, Pakta o građanskim i političkim pravima, kao i Pakta o ekonomskim, socijalnim, kulturnim pravima, izdvajaju se pravo na život, pravo na dostojanstvo, pravo na obrazovanje, pravo na zdravstvenu zaštitu, pravo na porodični život. Međutim, Rohindže nemaju mogućnost da uživaju u ovim pravima. Konkretno, Zakon o državljanstvu Burme iz 1982. godine im ne pruža pravo na državljanstvo. ${ }^{15}$ Rohindže nisu prepoznate ni kao jedna od 135 nacionalnih rasa koje žive u Mjanmaru. Posmatrani su kao Bengali muslimani bez države, te su tako Rohindže postali stranci u svojoj domovini. ${ }^{16} \mathrm{Na}$ osnovu ovog zakona čak $25 \%$ stanovništva nema pravo na državljanstvo, što ukazuje na diskriminatorni karakter samog zakona i njegove primene. Uveden je pojam „nacionalne rase“ i stanovništvo je podeljeno na ono koje je prvog i drugog reda. Baš iz razloga što im je uskraćeno pravo na državljanstvo, uskraćena su im i druga prava. Iako član 347 Ustava Mjanmara iz 2008. godine proklamuje pravo svakoj osobi da uživa jednaka prava i zaštitu pred zakonom, neka osnovna prava, poput prava na obrazovanje ili zdravstvenu zaštitu nisu obezbeđena za Rohindže. ${ }^{17}$ Čak će i za državljane politička prava biti ograničena, ukoliko im roditelj,

14 „Sporovi izmedu strana ugovornica u pogledu tumačenja, primene i izvršenja ove Konvencije, podrazumevajući tu i sporove koji se odnose na odgovornost neke države za genocid ili bilo koje drugo delo pobrojano u članu III, biće izneseni pred Međunarodni sud pravde, na traženje jedne od strana u sporu."

15 “Burma Citizenship Law," 15 October 1982, dostupno na: https:/ / www.refworld.org/ docid/3ae6b4f71b.html, datum pristupa 06/08/2020.

${ }^{16}$ Ziaur Rahman, Jhensanam Anusara, Bousaone Chanthamith, Saddam Hossain, Al Amin, "Rohingya crisis: identity of Rohingya Muslim in Myanmar", op. cit., p. 13.

16017 "Constitution of the Republic of the Union of Myanmar", član 347. 
supružnik ili dete nisu državljani. Primer za to je i Su Đi, čija deca nisu državljani Mjanmara, te samim tim ona ne može da se kandiduje za predsednika. ${ }^{18}$ Takođe, Naredbom 1/2005 predviđeno je da pripadnici islamske religije moraju da traže posebnu dozvolu za brak od relevantnih vlasti, a oni koji dobiju dozvolu moraju da ograniče broj dece. ${ }^{19}$ Rohindže imaju ograničeno i pravo na kretanje, te moraju da dobiju putne dozvole kako bi napustili svoj grad, a u severnoj provinciji Rakajn takođe važe ograničenja za kretanje između gradova. ${ }^{20} \mathrm{I}$ pre nego što su „operacije čišcenja“ počele da se sprovode u Rakajnu, državni zvaničnici su primoravali Rohindže da nose nacionalne kartice za verifikaciju. ${ }^{21}$

Pored zakonskih ograničenja, životni uslovi su Rohindžama otežani i time što se protiv njih sprovodi propaganda kroz različite javne nastupe. Sistematska kampanja mržnje protiv Rohindži podrazumeva i formiranje antirohindža pokreta, organizacije formirane 2013. godine od strane monaha Ašina Viratua (Ashin Wirathu), koji je tvrdio da su Rohindže invazivna vrsta. ${ }^{22}$ Pokret se naziva Udruženje za zaštitu rase i religije, a često se koristi skraćenica Ma Ba Tha. Ova grupa je izdejstovala zakone kojima se otežava sklapanje braka sa partnerima van svoje religije. Viratu optužuje Su Đi i civilnu vlast da pružaju podršku muslimanskoj manjini i da rade pod uticajem stranih sila. Iako su muslimani manjina, svega 5\% stanovništva pripada ovoj religiji, on smatra da oni ugrožavaju budističko stanovništvo. Vojna hunta ga je osudila na osam godina zatvora za izazivanje mržnje, a nakon izlaska iz zatvora je osnovao prethodno pomenuto udruženje. Jedno državno telo Mjanmara je 2017. godine uvelo zabranu javnog izlaganja i Viratu i njegovom udruženju, ali ono je samo promenilo svoj naziv i nastavilo sa svojim aktivnostima. ${ }^{23}$ Ovaj monah je zapravo postao poznat 2001. godini kada se priključio Pokretu 969, koji su međunarodni mediji opisali kao islamofobičan. Tada je počeo da širi mržnju

${ }^{18}$ Myanmar's discriminatory citizenship laws can and must be immediately reformed, https://www.icj.org/myanmars-discriminatory-citizenship-laws-can-and-must-beimmediately-reformed/, 08/08/2020.

${ }^{19}$ International Court of Justice, Application instituting proceedings and request for provisional measures, op. cit., para. 33.

${ }^{20}$ International Court of Justice, Application instituting proceedings and request for provisional measures, op. cit., para 34.

${ }^{21}$ Report of the independent international fact-finding mission on Myanmar, Human Rights Council, Septembar 2019, https:/ / documents-dds-ny.un.org/doc/UNDOC/ GEN/G19/236/74/PDF/G1923674.pdf?OpenElement, para. 24.

${ }^{22}$ International Court of Justice, Application instituting proceedings and request for provisional measures, op. cit., para. 39.

${ }^{23}$ Hannah Beech and Saw Nang, "He Incited Massacre, but Insulting Aung San Suu Kyi Was the Last Straw", The New York Times, 29 May 2019, https://www.nytimes.com /2019/05/29/world/asia/myanmar-wirathu-monk-buddhism.html. 
prema muslimanima. U maju 2019. godine vlasti Mjanmara su izdale nalog za hapšenje Viratua za govore mržnje protiv vlade i Su Đi. Trenutno se nalazi $u$ bekstvu, te se priprema suđenje $u$ odsustvu. ${ }^{24}$ Pored toga, monasi u Rakajnu su delili literaturu kojom su pozivali etničke stanovnike Rakajna da ne posluju sa Bengalima. Deljene su i publikacije kojima se poziva na neulaženje u muslimanske radnje i različiti časopisi koji o njima govore kao o crnom cunamiju. ${ }^{25}$

Još od sticanja nezavisnosti 1948. godine, Oružana snaga Mjanmara, tj. Tatmada (Tatmadaw), ima ključnu ulogu u održavanju reda i mira. General Ne Vin (Ne Win) izveo je državni udar 1962. godine i tada vojska preuzima sve državne institucije. Formirana je socijalistička stranka kojom su upravljali generali. Međutim, tek 1999. godine Tatmadau prvi put objavljuje svoj program, pod nazivom - Tri nacionalna uzroka: protiv dezintegracije Unije, protiv dezintegracije nacionalne solidarnosti i očuvanje nacionalnih interesa. ${ }^{26}$ Liberalizacija vojske počela je 2011. godine, što je rezultiralo i pobedom Nacionalne lige za demokratiju na izborima 2015. godine. Iako je partija koja podržava vojsku, Partija za solidarnost i razvoj unije, pretrpela gubitak na tim izborima, vojska je i dalje vrlo moćna. ${ }^{27}$ Tatmada ima veliku podršku većinskog stanovništva u Mjanmaru vezano za dela koja čine protiv Rohindži, a sudeći po odsustvu reakcije na nasilje koje sprovode nad njima, čini se da imaju podršku i Su Đi.

Sukobi između ARSA i vojske Mjanmara počeli su 9. oktobra 2016. godine kada je došlo do napada pobunjenika na burmanske carinike na granici sa Bangladešom. Naime, mali broj Rohindži naoružanih noževima i pištoljima napao je trojicu pripadnika granične policije u severnom Rakajnu. Nekoliko sati kasnije su Tatmada, odnosno vojska Mjanmara, reagovali. ${ }^{28}$ Od tada počinje operacija čišćenja kao odgovor na taj napad. ${ }^{29} \mathrm{U}$ ovim operacijama, izvršene su masovne egzekucije nad muškarcima i dečacima. ${ }^{30}$

${ }^{24}$ Shehab Sumon, “Ashin Wirathu: The Buddhist bin Laden", Arab News, 21 Avgust 2019, https://www.arabnews.com/node/1532846/world.

${ }^{25}$ International Court of Justice, Application instituting proceedings and request for provisional measures, op. cit., para. 39.

${ }^{26}$ Maung Aung Myoe, Building the Tatmadaw: Myanmar Armed Forces since 1948, Institute of Southeast Asian Studes, Singapore, 2009, p. 3.

${ }^{27}$ Ben Dunant, "It's good to be Tatmadaw", The Diplomat, 11 May 2017, https:/ / thediplomat.com/2017/05/its-good-to-be-the-tatmadaw/.

${ }^{28}$ International Court of Justice, Application instituting proceedings and request for provisional measures, op. cit., para. 48 .

${ }^{29}$ Catherine Renshaw, "Myanmar's Transition without Justice", Journal of Current Southeast Asian Affairs, 2019, p. 2.

${ }^{30}$ International Court of Justice, Application instituting proceedings and request for 162 provisional measures, op. cit., para. 53. 
Kuće i sela su spaljivani, što se videlo i na satelitskim snimcima. ${ }^{31}$ Vojska Mjanmara vršila je masovno seksualno nasilje, koje je podrazumevalo silovanje i seksualne napade, kao i grupna silovanja. ${ }^{32}$

Vrhunac sukoba dostigut je 25. avgusta 2017. godine. Samo osam sati pre nego što je napad počeo Kofi Anan, bivši Generalni sekretar UN, objavio je izveštaj u kojem je, između ostalog, preporučio da se Rohindžama omogući pravo na državljanstvo kao jedno od osnovnih prava na političko učešće. ${ }^{33}$ Kao razlog za nastavljanje „operacije čišćenja“, Mjanmar je naveo napad na vojnu bazu od strane ARSA-e, uz još nekoliko izolovanih incidenata. ${ }^{34}$ Ovi napadi su bili brutalniji od prethodnih. Pripadnici Tatmada su rano tog jutra ušli u sela, dok je većina stanovnika još spavala, i ispaljivali raketne bacače, minobacače i metke na kuće Rohindži. Mučili su, silovali i ubijali one koji su pokušavali da pobegnu. ${ }^{35}$ Ponovo je jedno od glavnih obeležja "operacije čiščenja“ bilo široko rasprostranjeno silovanje i seksualno nasilje. ${ }^{36}$

Brutalnosti režima u Mjanmaru prema Rohindža populaciji su nemilosrdne. Vlada poriče bilo kakva dela, niti dozvoljava nezavisne istrage. Na osnovu Ustava iz 2008. godine, vojska kontroliše ministarstva odbrane, unutrašnjih poslova i graničnih poslova. Zločini koje oružane snage vrše uključuju ubistva, prisilne nestanke, progone, ograničenja kretanja i uskraćivanje hrane i zdravstvene zaštite. Užasna seksualna nasilja se vrše nad ženama i mladim devojkama od strane vojske. ${ }^{37}$ Komisija za utvrđivanje činjenica utvrdila je i da su i prema Rohindža zatvorenicima vršena mučenja i fizička zlostavljanja uz pristanak vlasti u zatvoru. ${ }^{38}$ Iako Mjanmar tvrdi da je završen poslednji talas "operacije čišćenja“ misija UN za utvrđivanje činjenica pronašla je da su Rohindže i dalje meta napada Vlade u cilju brisanja njihovog identiteta i njihovog izmeštanja iz Mjanmara. ${ }^{39} \mathrm{U}$ poslednjem izveštaju se tvrdi da se oko 600.000 Rohindži koji su ostali u Mjanmaru nalazi u ozbiljnoj i značajnoj opasnosti od daljih genocidnih radnji. ${ }^{40}$

\footnotetext{
${ }^{31}$ Ibid., para 54.

${ }^{32}$ Ibid., para. 62.

${ }^{33}$ Catherine Renshaw, “Myanmar's Transition without Justice”, op. cit., p. 4.

${ }^{34}$ International Court of Justice, Application instituting proceedings and request for provisional measures, op. cit., para. 72 .

${ }^{35}$ Ibid., para. 75.

${ }^{36}$ Ibid., para. 91.

${ }^{37}$ Abigail Knudson, “The Rohingya Refugee Crisis \& International Implications", p. 6.

${ }^{38}$ Report of the independent international fact-finding mission on Myanmar, op. cit., para. 27-28.

${ }^{39}$ International Court of Justice, Application instituting proceedings and request for provisional measures, op. cit., para. 99.

${ }^{40}$ Ibid., para. 110.
} 
Pored toga što su ugrožena mnoga ljudska prava, sloboda medija u Mjanmaru je u izuzetno nepovoljnoj situaciji. Ova sloboda je preduslov za postojanje i primenu mnogih drugih, ali i informisanje kako međunarodne zajednice tako i celokupnog stanovništva Mjanmara o dešavanjima. Tu se naročito izdvajaju dve situacija. Prvo je vladino opširno oslanjanje na Krivični zakon o kleveti i klauzulu o kleveti u Zakonu o telekomunikacijama iz 2013. godine. Građani su bili zatvarani za klevetanje Su Đi na Fejsbuku. Drugi slučaj jeste porast antimedija populističkog narativa, formiranog od strane budističkih nacionalista, koji optužuju medije da su promuslimanski i prorohindža pristrasni, o čemu je ranije bilo reči ${ }^{41}$ Još 2014 . godine vlada Mjanmara naložila je medijima da ne uključuju u svoje vesti pitanja vezana za Rohindža muslimane. Sloboda medija je i inače važna za Mjanmar, s obzirom na to da je to zemlja koja se 60 godina nalazila pod vojnom vlasti i mediji su bili cenzurisani, a od 2011. godine se Mjanmar nalazi na demokratskom putu. Zakoni koji uređuju slobodu medija su doneti 2014. godine. Oni su po prvi put uveli slobodu medija i time ujedno ohrabrili regionalne medije da omoguće povratak novinara koji su progonjeni kao i davanje viza stranim novinarima. Nažalost, nada da će se sloboda medija dalje razvijati izgubljena je 2015. godine sa dolaskom na vlast Nacionalne lige za demokratiju. ${ }^{42}$

Zanimljivi su i nestanci internet konekcije prijavljeni 2019. i 2020. godine. Još 2016. godine Ujedinjene nacije su prepoznale pravo na pristup internetu kao ljudsko pravo. Vlasti Mjanmara su pre više od godinu dana naredili gašenje interneta $u$ Rakajnu. Zakon o telekomunikacijama Mjanmara je problematičan, jer nije usklađen sa standardima međunarodnih ljudskih prava. Upravo na osnovu ovog zakona, koji je donet 2013. godine, ljudima je suđeno za klevetu na internetu, a dolazilo je i do hapšenja novinara. Mjanmar je delimično izmenio ovaj zakon 2017. godine, ali i dalje nadležno ministarstvo ima mogućnost da suspenduje telekomunikacione usluge $u$ slučaju hitnosti. ${ }^{43}$ Na ovaj način je Mjanmaru olakšano da šalje u svet fotografije koje bi mogle da dovedu u zabludu, poput snimka na kojem čovek obučen u muslimansku odeću spaljuje kuću u Rakajn provinciji. Mjanmar je ovo iskoristio kao argument da nisu oni vršili spaljivanje poseda, već sami pripadnici Rohindža manjine. Kasnije se ispostavilo da se radi o Indijcu koji se samo prerušio. Ovo ukazuje na to da je teško utvrditi autentičnost

\footnotetext{
${ }^{41}$ Matteo Fumagalli, "Myanmar 2019: The lady and the generaux", op. cit., p. 320.

${ }^{42}$ Edward Parker, "What is the Future of the Media in Myanmar?", The Diplomat, 11 September 2017, https:/ / thediplomat.com/2017/09/ what-is-the-future-of-the-mediain-myanmar/.

${ }^{43}$ Jiuen Pyun, "Myanmar Must End Its Internet Shutdown", The Diplomat, 15 Jul 2020,

164 https://thediplomat.com/2020/07/myanmar-must-end-its-internet-shutdown/.
} 
podataka. Iz tog razloga, postoji potreba za formiranjem nezavisnih komisija koje bi istražile situaciju.

Jedan od prvih izveštaja koji se pojavio bio je 2017. godine izveštaj koji je objavio Human Rights Watch. U njemu su izneta svedočenja devojaka i žena koje su bile žrtve seksualnog nasilja. ${ }^{44}$

Formirana je i Savetodavna komisija za državu Rakajn, na čijem čelu se nalazio Kofi Anan. Ta komisija formirana je 2016. godine po pozivu Su Đi (iako je i dalje poricala etničko čišćenje) i njen zadatak bio je da preporuči vladi kako da se obezbedi mir u Rakajnu. U izveštaju koji je podnet 23. avgusta 2017. godine, samo dva dana pre eskalacije sukoba, predlaže se da vlada Mjanmara preduzme hitne konkretne mere kako bi se poboljšali ekonomski razvoj i socijalna pravda u Rakajnu i da bi se ublažilo nasilje i neprijateljstvo između budista i Rohindža muslimana. Dakle, Savetodavna komisija je trebalo da pruži preporuke vladi Mjanmara kako bi osigurali mir i prosperitet $\mathrm{u}$ Rakajnu. Od podnošenja izveštaja u avgustu 2017. godine, na vladi Mjanmara je da odluči kako će dalje postupati. Komisija je bila formirana po zahtevu vlade Mjanmara i šest od devet članova su bili državljani Mjanmara. Svoj posao su vršili tako što su sprovodili konsultacije i dijaloge sa grupama iz Rakajna i lokalnim liderima. ${ }^{45}$

Visoki komesarijat UN za ljudska prava takođe je objavio izveštaj svoje nezavisne pronalazačke misije, kao i sama država Mjanmar. Čak i u izveštajima iz ove godine, Mjanmar poriče postojanje bilo kakvih dokaza o genocidu. Takođe, novinska agencija Rojters sprovodila je istraživanje u septembru 2017. godine koje se završilo hapšenjem novinara. Amnesty International takođe izveštava da dolazi do hapšenja građana koji izražavaju nezadovoljstvo sadašnjom vlasti i kršenjem ljudskih prava. ${ }^{46}$

U martu 2017. godine Savet za ljudska prava Ujedinjenih nacija osnovao je Nezavisnu međunarodnu komisiju za utvrđivanje činjenica u Mjanmaru, sa zadatkom da utvrdi činjenice i okolnosti koje ukazuju na kršenja ljudskih prava od strane vojske i oružanih snaga. Mandat je okončan u septembru 2019. godine. ${ }^{47}$ Nalazi ove komisije su naročito značajni. Ova misija je

${ }^{44}$ Human Rights Watch, "All of my body was pain: Sexual Violence against Rohingya Women and Girls in Burma", 16 November 2017, https://www.hrw.org/report/ 2017/11/16/all-my-body-was-pain/sexual-violence-against-rohingya-women-andgirls-burma.

${ }^{45}$ Advisory Commission on Rakhine State, http://www.rakhinecommission.org/, 21/08/2020.

${ }^{46}$ Amnesty International, Myanmar 2019, https://www.amnesty.org/en/countries/ asia-and-the-pacific/myanmar/report-myanmar/, 08/08/2020.

${ }^{47}$ Independent International Fact-Faction Mission on Myanmar, United Natons Human Rights Council, https://www.ohchr.org/en/hrbodies/hrc/myanmarffm/pages/ index.aspx, 07/08/2020. 
sprovela preko 600 intervjua sa žrtvama i svedocima, kao i preko 250 konsultacija sa nevladinim organizacijama, istraživačima i svedocima. $\mathrm{Na}$ osnovu svih prikupljenih dokaza, Komisija je podnela izveštaj o detaljnim nalazima u septembru 2018. godine u kojem stoji da su prisutni faktori koji potvrđuju genocidnu nameru i traže da se istraže i tuže visoki zvaničnici vojske Mjanmara. U završnom izveštaju, u septembru 2019. godine, potvrđeno je da je $u$ Mjanmaru $u$ toku genocid. ${ }^{48}$ Iako Mjanmar tvrdi da je završio sa poslednjim „operacijama čišćenja“, Misija UN za utvrđivanje činjenica je podnela izveštaj u septembru 2019. godine Savetu UN za ljudska prava, da su stava da su Rohindže i dalje na meti napada vlade u cilju da se briše njihov identitet i da se uklone iz Mjanmara. ${ }^{49}$ Prisilno izgladnjavanje se vrši konfiskacijom zemljišta sa hranom koju oni koriste. ${ }^{50}$ Misija je u izveštaju navela i da su Tatmada i etnički Rakajni namerno ubijali ili oduzimali stoku bez dozvole ili naknade. ${ }^{51}$ Izveštaj iz septembra 2019. godine tvrdi da je oko 600 hiljada Rohindži, koji su ostali u Mjanmaru, u stvarnoj i značajnoj opasnosti od genocidnih radnji države Mjanmar. ${ }^{52}$

Savet Ujedinjenih nacija za ljudska prava formirao je i Međunarodni istražni mehanizam koji je preuzeo rad Komisije za pronalaženje činjenica, kako bi nastavili prikupljanje i očuvanje dokaza međunarodnih zločina u cilju pripreme budućih postupaka. ${ }^{53}$ Osnovan je u septembru 2018. godine rezolucijom 39/2, sa zadatkom da prikuplja dokaze o najtežim krivičnim delima i kršenjima međunarodnog prava, kao i da pripremi dokumente o krivičnom gonjenju, na osnovu prethodno prikupljenih informacija od strane Komisije za pronalaženje činjenica. Ovaj mehanizam je postao operativan 30. avgusta 2019. godine. ${ }^{54}$

Bivši specijalni izvestilac Ujedinjenih nacija o situaciji sa ljudskim pravima u Mjanmaru, Jang Li, sprovela je opširno utvrđivanje činjenica $u$ odnosu na kampanju protiv Rohindži koja, između ostalog, može da posluži za utvrđivanje genocidne namere. Ona je izvestila o napadima na kuće koje su zapalili pripadnici bezbednosnih snaga, gde se često dešavalo da ljudi ostanu zarobljeni unutra i da su cela sela bivala porušena do zemlje. Zabeležila je svedočenja roditelja koji su viđali svoju decu kako gore u plamenu. Oružane snage Mjanmara su odvajale i odvodile muškarce i

${ }^{48}$ International Court of Justice, Application instituting proceedings and request for provisional measures, op. cit., para. 11-14.

${ }^{49}$ Ibid., para. 99.

${ }^{50}$ Ibid., para. 104.

${ }^{51}$ Ibid., para 106.

52 Ibid., para. 110.

${ }^{53}$ Catherine Renshaw, "Myanmar's Transition without Justice”, op. cit., p. 11.

${ }^{54}$ Independent Investigative Mechanism for Myanmar, https://www.ohchr.org/EN/

166 HRBodies/HRC/IIMM/Pages/Index.aspx. 
dečake od svojih porodica. Zapisala je i svedočenje devojaka i žena koje su bile silovane, a neke su i nakon toga ubijane i zakopavane žive u svojim kućama. Na kraju je zaključila da je sve više sigurna da ovi zločini poprimaju oblik genocida, te da bi glavni komandant vojske Mjanmara i ostali odgovorni pojedinci trebalo da snose odgovornost za genocid jer su delali u ime države. ${ }^{55}$

Posledica progona jeste i izbeglička kriza koja je počela 2017. godine. $\mathrm{Na}$ desetine hiljada civila prinuđeno je da napusti svoje domove. Naročito je pogođeno starije stanovništvo, zbog pojačane potrebe za zdravstvenom zaštitom i domom. ${ }^{56}$ Najveći broj Rohindži je izbegao u Bangladeš, Tajland i Maleziju. Između Bangladeša i Mjanmara potpisan je Memorandum o repatrijaciji Rohindža izbeglica u Rakajn 2018. godine. Međutim, u razgovoru sa predstavnicima Ujedinjenih nacija izbeglice su izjavile da ne žele da se vrate jer osećaju strah. Sa druge strane, nemaju pravni status u Bangladešu, te im je limitiran pristup obrazovanju, zdravstvenim ustanovama i uopšte zaštiti koju izbeglice imaju prema međunarodnom pravu, s obzirom na to da nisu prepoznati kao takvi u pravnom smislu. ${ }^{57}$

\section{Uloga Gambije u slučaju pred Međunarodnim sudom pravde}

Ono što privlači pažnju u ovom slučaju jeste to što je postupak pokrenula Gambija. Gambija je najmanja država u kontinentalnoj Africi koja je 1965. godine stekla nezavisnost i postavila se kao regionalni lider $\mathrm{u}$ zaštiti ljudskih prava. Sedište Afričke komisije o ljudskim pravima i pravima naroda nalazi su njenoj prestonici. Dauda Džavara (Dawda Jawara), tadašnji predsednik, pomogao je da se 70-ih i 80-ih godina prošlog veka postave temelji ovom pravcu. Afrička povelja o ljudskim pravima poznata je i kao Bandžulska povelja, upravo po prestonici Gambije. Sedište Afričke komisije o ljudskim pravima i pravima naroda nalazi su njenoj prestonici. ${ }^{58}$

Godine 1994. dolazi do vojnog udara i na vlast dolazi Jahia Džame (Yahua Jammeh). Vladavina Džame trajala je 22 godine i za to vreme vladao je diktatorskim režimom uz široko rasprostranjenu upotrebu nasilja. Godine 2017. on je pobegao u Ekvatorijalnu Gvineju i dolazi do ponovne smene vlasti

${ }^{55}$ International Court of Justice, Application instituting proceedings and request for provisional measures, op. cit., para. 7-8.

${ }^{56}$ Amnesty International, Myanmar 2019, https://www.amnesty.org/en/countries/ asia-and-the-pacific/myanmar/report-myanmar/, 08/08/2020.

${ }^{57}$ Abigail Knudson, “The Rohingya Refugee Crisis \& International Implications", p. 12.

${ }^{58}$ Oumar Ba, "This tiny African country got the U.N.'s top court to investigate Myanmar for genocide", The Washington Post, 29 Januar 2020, https://www.washington post.com/politics/2020/01/29/this-tiny-african-country-got-uns-top-courtinvestigate-myanmar-genocide/. 
u Gambiji. Nakon održanih izbora 2016. godine Džame na njima neočekivano gubi i na vlast dolazi opozicioni lider Adama Barou (Adama Barrow) i posvećuje se zaštiti ljudskih prava i iskorenjivanju korupcije. ${ }^{59}$ Komisija za istinu, pomirenje i povraćaje je nezavisna institucija koja je osnovana s ciljem da se rasvetli činjenično stanje i da se istraže povrede ljudskih prava vršene $u$ periodu od 1994. do 2017. godine. Cilj je izražen krilaticom „Nikada više ${ }^{\prime .}{ }^{60}$ Sa druge strane, proces demokratske tranzicije u Gambiji ne prolazi bez kontroverzi. Tambadou, ministar pravde, oslobodio je četiri pripadnika paralimitarnih jedinica prethodne vlasti da bi, zauzvrat, svedočili pred Komisijom. Neke žrtve prethodnog režima su to protumačile kao izdaju. Smatraju da je pokretanje postupka protiv Mjanmara potez za javnost. ${ }^{61}$

Razlog pokretanja postupka zapravo je lične prirode. Ministar pravde Tambadou je ujedno i na čelu pravnog tima Gambije pred Međunarodnim sudom pravde. On je dugo radio kao tužilac u Međunarodnom krivičnom tribunalu za Ruandu. Pukom slučajnošću je u maju 2018. godine posetio izbeglički kamp u kojem se nalaze Rohindža muslimani u Bangladešu i ono što je tamo video ga je podsetilo na zločine iz Ruande. Naime, na taj put je trebalo da bude poslat Ministar spoljnih poslova, ali pošto je bio sprečen, umesto njegao otišao je Tambadou. Zajedno sa delegacijom Organizacije islamske saradnje obišao je izbegličke kampove u Bangladešu, konkretno Koks Bazar, gde se nalazi na stotine hiljada Rohindža muslimana. ${ }^{62}$

Iako Gambija nije bogata zemlja, sa bruto domaćim proizvodom od 1,48 milijardi dolara, pružena joj je jaka podrška i pomoć. Naime, opšte je poznato da su troškovi vođenja postupka pred Međunarodnim sudom pravde izrazito visoki. Organizacija islamske saradnje sa svojih 57 država članica i advokatska kancelarija iz Sjedinjenih Američkih Država Foley Hoag pomažu u finansiranju. ${ }^{63}$ Ipak, ministar pravde Gambije kaže da nije samo muslimanska

${ }^{59}$ Aaron Ross, "With memories of Rwanda: The Gambian minister taking on Suu Kyi”, Reuters, 5 Decembar 2019, https:/ / www.reuters.com/article/us-myanmar-rohingyaworld-court-gambia/with-memories-of-rwanda-the-gambian-minister-taking-on-suukyi-idUSKBN1Y91HA.

${ }^{60}$ Truth, Reconciliation and Reparation Commission, http://www.trrc.gm/, 07/08/2020.

${ }^{61}$ Louise Hunt, "Gambia's genocide case against Myanmar shows that smaller countries can also help balance the scales of international justice", 27 Mart 2020, https:/ / www.equaltimes.org/gambia-s-genocide-case-against\#.Xy0bGSgzbIV.

${ }^{62}$ Aaron Ross, "With memories of Rwanda: The Gambian minister taking on Suu Kyi", op. cit.

${ }^{63}$ Danielle Paquette, "Why a tiny African country is taking the Rohingya's case to the world court", The Washington Post, 12 Novembar 2019, https://www.washington post.com/world/africa/why-a-tiny-african-country-is-taking-the-rohingyas-case-tothe-world-court/2019/11/12/f491d5a4-04cd-11ea-9118-25d6bd37dfb1_story.html\#

168 comments-wrapper. 
solidarnost razlog pokretanja postupka, već se radi o humanosti. ${ }^{64}$ Takođe, Gambija na ovaj način želi da ponovo uspostavi svoj status regionalnog zaštitnika ljudskih prava i da bude primer drugim državama. ${ }^{65}$

\section{Su Đi i njena uloga u postupku pred Međunarodnim sudom pravde}

Specifičnost ovog slučaja je i u tome ko zastupa Mjanmar pred Međunarodnim sudom pravde. Iako je često praksa da se formira pravni tim na čijem čelu se nalaze iskusni pravnici, ovog puta to nije slučaj. Mjanmar predstavlja Ong San Su Đi (Aung San Suu Kyi). Ona je burmanska prodemokratska političarka. Na čelu je Nacionalne lige za demokratiju i dobitnica Nobelove nagrade za mir 1991. godine. Njen otac bio je Ong San, "otac nacije“, osnivač moderne države i Tatamada. Obrazovanje je stekla u Indiji, a potom na Oksfordu. Časopis „Tajm“ (Time) ju je 1999. godine nazvao Gandijevim detetom zbog zalaganja za nenasilje. Sve ukupno je 15 godina provela u kućnom pritvoru u svojoj zemlji do 2015. godine kada njena partija dolazi na vlast. Međutim, pošto joj je muž Englez i deca joj žive u Londonu i imaju englesko državljanstvo, Ustav Mjanmara joj nije dozvolio da se kandiduje za predsednika. Umesto toga, na čelu je Ministarstva spoljnih poslova i još nekih ministarstava, a od 2016. godine obavlja funkciju državne savetnice, što je ekvivalent premijeru. Zbog odsustva reakcije na nasilje nad Rohindža muslimanima, 2017. godine predstavnici nevladinih organizacija su tražili da se povuče Nobelova nagrada koju je primila. Pored toga, grad London je povukao počasnu nagradu koju joj je dodelio 2017. godine. ${ }^{66}$

Kada je u pitanju njen odnos sa vojskom, u periodu od 2010. do 2018. godine, Su Đi je preduzela razne mere kako bi se osigurala da vojska nema interes $u$ retribuciji. Kroz javne izjave i gestove podrške, Su Đi je stalno potvrđivala da Nacionalna liga za demokratiju ne traži odgovornost za radnje počinjene $\mathrm{u}$ doba vojne vlasti, čak je i nazivala Tatamada vojskom njenog oca i da joj se ona dopada. ${ }^{67} \mathrm{U}$ odnosu na Rohindže, vojska je dugo tražila njihovo izmeštajanje iz provincije Rakajn. General Ne Vin je 1962. godine militarizovao državu pod nacionalnističkom ideologijom ,jedna krv, jedan glas, jedna

${ }^{64}$ Aaron Ross, "With memories of Rwanda: The Gambian minister taking on Suu Kyi", op. cit.

65 "Rohingya crisis: The Gambian who took Aung San Suu Kyi to the world court", BBC News, 23 Januar 2020, https:/ / www.bbc.com/news/world-africa-51183521.

${ }_{66}$ "City of London revokes honour granted to Myanmar's Suu Kyi", Al Jazeera and News Agencies, 5 Mart 2020, https://www.aljazeera.com/news/2020/03/city-londonrevokes-honour-granted-myanmar-suu-kyi-200305152434073.html.

${ }^{67}$ Catherine Renshaw, "Myanmar's Transition without Justice”, op. cit., p. 7. 
komanda". Od tada je počela strategija degradiranja života Rohindži, kako bi se naterali da pobegnu iz zemlje ili da umru od gladi ili bolesti. ${ }^{68}$

Odluka da sama zastupa svoju državu pred Međunarodnim sudom pravde verovatno je posledica toga što se bliže izbori pa želi da na ova način pruži podršku vojci i da se prikloni većinskom budističkom stanovništvu. Parlamentarni izbori su zakazani za 8. novembar 2020. godine. Ovi izbori biće test za tranciziciju od vojne vlasti ka demokratiji. ${ }^{69}$ Jedno od izbornih obećanja 2015. godine bila je promena ustava. Nacionalna liga za demokratiju je formirala u januaru 2019. godine komitet koji bi trebalo da se bavi ustavnim amandmanima. Vojno orijentisana Partija za solidarnost i razvoj Unije protivila se tome na ulicama, naglašavajući koliko je važno da se očuva suština ustava iz 2008. godine, naročito uloga vojske. Bez podrške vojske, Nacionalna liga za demokratiju je počela sa procesom ustavnih amandmana. Posebnu pažnju privukao je član 261 Ustava, koji reguliše postavljanje šefova ministarstava država i regiona na osnovu kojeg su moći podnacionalne vlasti ograničene. Predlog Partije za solidarnost i razvoj Unije bio je da se dozvoli zakonodavstvu i državnog i regionalnog nivoa da ih imenuje. To bi bila mera ka decentralizaciji koja bi mogla da dovede do toga da se u Rakajn državi postavljaju predstavnici Nacionalne partije Arakana. ${ }^{70}$

U nastupima pred Međunarodnim sudom pravde nijednom nije iskoristila termin Rohindža, što se može tumačiti kao njeno poricanje postojanja manjine. Zapravo, još tokom 2017. godine zatražila je od Savetodavne komisije za Rakajn, koju je formirao Kofi Anan, da o njima govore kao o Muslimanima ili o muslimanskoj zajednici u Rakajn državi, umesto o Rohindža muslimanima. ${ }^{71}$ Iskazala je da ona zapravo pokušava da ih podgine iz siromaštva. Tvrdi da genocidna namera ne postoji, a dokaz za to je da je vlada Mjanmara sprovodila istrage i ohrabrivala ih da se vrate kućama. Njen nastup je izrazito odbramben i optužila je strance da ne razumeju kompleksnu etničku situaciju u Mjanmaru. Branila je radnje vojske, koristeći samoodbranu i tvrdila da su vojne operacije vršene isključivo protiv pobunjenika ili terorista. U samo jednom delu se osvrnula na zlodela vojske, a to je da su možda koristili disproporcionalnu silu protiv Rohindži. ${ }^{72}$

\footnotetext{
${ }^{68}$ Ibid., p. 10.

69 "Myanmar sets November 8 date for general election", Al Jazeera and News Agencies, 2 Jul 2020, https://www.aljazeera.com/news/2020/07/myanmar-sets-november-8date-general-election-200702033020917.html.

${ }^{70}$ Matteo Fumagalli, "Myanmar 2019: The lady and the generaux", op. cit., pp. 317-318.

${ }^{71}$ Wendell Glenn P. Cagape, "Finding Foucault in the Rohingya Discourses", p. 5.

${ }^{72}$ Abigail Knudson, “The Rohingya Refugee Crisis \& International Implications”, p. 11.
} 


\section{Postupak pred Međunarodnim sudom pravde}

S obzirom na to da su i Gambija i Mjanmar potpisnice Konvencije o sprečavanju i kažnjavanju zločina genocida, nadležnost Međunarodnog suda pravde formirana je na bazi člana 9. Nijedna od ovih dveju država nije izjavila rezervu na Konvenciju. Sa metodološke tačke gledišta, tužba se u velikoj meri odnosi na nalaze iz 2018. i 2019. godine Nezavisne međunarodne misije za utvrđivanje činjenica za faktičku osnovu tužbe. Što se tiče pravne osnove, Gambija se oslanja na to da su obe države stranke Konvencije o genocidu i da nijedna nije izjavila rezervu na član 9. Gambija tvrdi da je zabrana genocida jus cogens norma i da je obaveza erga omnes, te na osnovu toga podnosi tužbu. Gambija je postavila za ad hoc sudiju Navanethem Pillay, bivšu predsednicu Međunarodnog tribunala za Ruandu, sudiju Međunarodnog krivičnog suda i šeficu OHCHR. ${ }^{73}$

U tužbi koju je Gambija podnela nalaze se činjenični navodi potkrepljeni nalazima komisija koji ukazuju na to da se u Rakajn provinciji sprovodi genocid $i$ da postoji genocidna namera. $U$ ovom radu su u više navrata davani argumenti koji idu $\mathrm{u}$ prilog tome da se u Mjanmaru sprovodi genocid. Na bazi toga, Gambija je tražila od Međunarodnog suda pravde da utvrdi odgovornost Mjanmara za kršenja Konvencije o sprečavanju i kažnjavanju zločina genocida, i to: izvršenje genocida, zavera da se sprovede genocid, direktno i javno navođenje na vršenje genocida, pokušaj vršenja genocida, saučesništvo u genocidu i neuspeh u sprečavanju i kažnjavanju genocida, neuspeh u donošenju adekvatnog zakona koji bi stavio u primenu Konvenciju o sprečavanju i kažnjavanju zločina genocida. ${ }^{74}$

Između ostalog, podnet je i zahtev za donošenje privremenih mera. Privremene mere po pravilu se donose onda kada postoji velika opasnost da će nastati šteta koja ne bi mogla da se popravi i ako je hitno da se takva odluka donese. Traži se da Mjanmar odmah preduzme sve mere kako bi sprečio radnje koje bi doprinele genocidu, uključujući ubistva i fizičko zlostavljanje, silovanja i druge forme seksualnog nasilja, spaljivanja kuća i sela, uništavanje zemlje, oduzimanje hrane i bilo koje namerno stavljanje grupe u uslove života koje bi dovelo do fizičkog uništenja, zatim da se osigura da bilo koja vojna, paravojna ili druga oružana jedinica, ili organizacija i osobe pod njenom kontrolom, neće vršiti genocidne radnje protiv ove grupe, da Mjanmar neće uništavati dokaze vezane za događaje koji su opisani u tužbi, da Mjanmar i Gambija neće preduzeti nikakve radnje, i da će obe strane dati sudu izveštaj

${ }^{73}$ Priya Pillai, "The Gambia v Myanmar at the International Court of Justice: Points of Interest in the Application", 21/11/2019, https://opioniojuris.org/2019/11/13/thegambia-v-myanmar-at-the-international-court-of-justice-points-of-interest-in-theapplication/.

${ }^{74}$ International Court of Justice, Application instituting proceedings and request for provisional measures, op. cit., para. 111. 
o preduzetim merama ukoliko naredba o privremenim merama bude doneta ne kasnije od četiri meseca od njenog donošenja. ${ }^{75}$

Tambadou je izjavio da $\mathrm{u}$ izveštaju koji Mjanmar treba da podnese očekuje da Mjanmar pokaže da preduzimaju radnje kako bi sprečili genocid, da pokažu da se uzdržavaju od genocida i da ukažu na to koje su to mere koje sprovode kako bi očuvali dokaze. ${ }^{76}$

Međunarodni sud pravde je 23. januara doneo Naredbu kojom utvrđuje neophodne privremene mere. Mjanmar je u obavezi da preduzme sve mere kako bi sprečio vršenje radnji koje čine genocid, da se osigura da vojska niti paravojne jedinice neće vršiti genocidne radnje. Država, takođe, mora da preduzme mere na osnovu kojih će obezbediti očuvanje dokaza i mora u roku od četiri meseca da dostavi izveštaj sudu, a od tada na svakih šest meseci dok se ne donese presuda. ${ }^{77}$ Usled toga, $\mathrm{u}$ aprilu 2020 . godine Mjanmar je doneo dve direktive. Direktiva No 1/2020 kaže da su odgovorne vlasti dužne da osiguraju da niko ko se nalazi pod njihovom kontrolom neće činiti bilo koje radnje koje bi vodile tenzijama. Direktiva No 2/2020 zabranjuje svim ministarstvima i vladi Rakajna da unište bilo koje dokaze koji bi mogli voditi ka utvrđivanju genocida. Izveštaj je podnet nakon četiri meseca od donošenja privremenih mera, ali nije dostupan javnosti. ${ }^{78}$

Portparol brigadne vojske Mjanmara general Zaw Min Tun je na konferenciji za štampu izjavio da vojska sarađuje sa Nezavisnom komisijom za istragu koju je formirala vlada na osnivanju ratnih sudova. Izjavio je da komisija nije pronašla dokaze o genocidu. ${ }^{79}$

Radio Slobodna Azija ima snimak na kojem su Rohindža izbeglice koje gledaju izricanje privremenih mera od strane Međunarodnog suda pravde. Intervju sa nekima od njih ukazuje na to da se javlja određena doza nade. Ipak, obeshrabruje to što je Mjanmar stava da neće preduzimati posebne radnje prikupljanja dokaza, osim naredbe da se dokazi ne uništavaju. Ostaje da se vidi kakvog je uticaja donošenje privremenih mera. ${ }^{80}$

${ }^{75}$ Ibid., para. 132.

${ }^{76}$ Carol Guensberg, "A voice for Justice for Rohingyas, Rwandas and Gambians", Voice of America News, 27 May 2020, https://www.voanews.com/africa/voice-justicerohingyas-rwandans-and-gambians.

${ }^{77}$ International Court of Justice, Application of the Convention on the Prevention and Punishment of the Crime of Genocide, Republic of the Gambia v. Republic of the Union of Myanmar, Order, 23 January 2020, para. 86.

${ }^{78}$ Anthony Deutsch and Toby Sterling, "Myanmar updates U.N. court on 'confidential' Rohingya measures", Reuters, 25 Maj 2020, https://www.reuters.com/article/usmyanmar-rohingya-world-court/ myanmar-updates-u-n-court-on-confidentialrohingya-measures-idUSKBN231124.

${ }^{79}$ Carol Guensberg, "A voice for Justice for Rohingyas, Rwandas and Gambians", op. cit.

${ }^{80}$ D. Wes Rist, "What does the ICJ decision on The Gambia v. Myanmar mean?", https:// www. asil.org/insights/volume/24/issue/2/what-does-icj-decision-gambia-

172 v-myanmar-mean. 


\section{Zaključna razmatranja}

Ovaj slučaj je istorijski, jer se prvi put desilo da postupak pokrene država koja nije direktno povezana sa slučajem o kojem se radi. Dakle, za pokretanje postupka vezanih za ovakva dela nije potrebna direktna veza, već svaka država može da ima tu mogućnost. Kakav god da bude ishod ovog postupka, veliki značaj jeste privlačenje pažnje na ovaj slučaj. Sama činjenica da je Gambija podnela tužbu je značajan korak u traženju odgovornosti i dobar put za utvrđivanje odgovornosti države za genocid. Javlja se nada da će ovo biti podstrek drugim državama da se ohrabre u podnošenju tužbe za sva dela koja su erga omnes. Pored toga, biće zanimljivo pratiti i posledice na politički život u Mjanmaru, konkretno na rezultate izbora koji ih očekuju u novembru 2020. godine i rangiranje Su Đi na istim.

U slučajevima poput ovog, kada već ima nastradalih u velikom broju, Međunarodni sud pravde ne može da promeni već nanetu štetu, ali može da utiče na dalji razvoj prakse time što će doneti adekvatnu presudu u kojoj će osuditi krive i odrediti adekvatnu naknadu štete, a time ujedno vratiti veru u pravdu. Ali ono što je od posebnog značaja, a predstavlja stav autora ne samo kada je u pitanju Međunarodni sud pravde već i celokupno međunarodno javno pravo i čak pravo u celini, jeste neophodnost da se stavi interes pojedinca, čoveka na prvo mesto.

$\mathrm{Ne}$ postoji puno mogućnosti u kojima međunarodno pravo i međunarodni i regionalni sudovi mogu direktno da odlučuju o pravima pojedinca. Možemo navesti Evropski sud za ljudska prava, kao jedan od retkih primera. Kada je u pitanju genocid, to pitanje predstavlja veoma važno poglavlje u praksi Međunarodnog suda pravde. Naime, to je jedini sud koji o tome pitanju može da odlučuje, a genocid predstavlja vrhunac zločinačkog ponašanja pojedinca sa posledicama koje su često običnom čoveku nesagledive, kao i strahote tog zločina. Predviđanja ishoda ovog postupka je nezahvalno davati, pogotovo što nas verovatno čeka još nekoliko godina postupanja. Međunarodni sud pravde je konzervativan sud, koji se veoma teško odlučuje da dâ definitivne odgovore. Sa druge strane, ovaj slučaj može biti idealna prilika da se pokaže odnos međunarodne zajednice prema sprovođenju genocida u bilo kom delu sveta.

\section{Bibliografija}

"Aung San Suu Kyi named in Argentine lawsuit over crimes against Rohingya", Bangkok Post, 14 Novembar 2019, https://www.bangkok post.com/world/1793549/aung-san-suu-kyi-named-in-argentinelawsuit-over-crimes-against-rohingya.

"City of London revokes honour granted to Myanmar's Suu Kyi", Al Jazeera and News Agencies, 5 Mart 2020, https://www.aljazeera.com/news/ 
2020/03/city-london-revokes-honour-granted-myanmar-suu-kyi200305152434073.html.

"Myanmar sets November 8 date for general election", Al Jazeera and News Agencies, 2 Jul 2020, https://www.aljazeera.com/news/2020/07/ myanmar-sets-november-8-date-general-election-200702033020917.html.

"Myanmar's discriminatory citizenship laws can and must be immediately reformed", https:// www.icj.org/myanmars-discriminatory-citizenshiplaws-can-and-must-be-immediately-reformed/, 08/08/2020.

"Rohingya crisis: The Gambian who took Aung San Suu Kyi to the world court", BBC News, 23 Januar 2020, https://www.bbc.com/news/worldafrica-51183521.

Adanan, Amina, "Symposium on the Genocide Convenction: Reflecting on the Genocide Convention at 70: How genocide became a crime subject to universal jurisdiction", EJIL: Talk, Blog of the European Journal of International Law, 16 Maj 2019, https:/ / www.ejiltalk.org/symposiumon-the-genocide-convention-reflecting-on-the-genocide-convention-at70-how-genocide-became-a-crime-subject-to-universal-jurisdiction/.

Advisory Commission on Rakhine State, http:/ / www.rakhinecommission. org/, 21/08/2020.

Amnesty International, Myanmar 2019, https://www.amnesty.org/en/ countries/asia-and-the-pacific/myanmar/report-myanmar/, 08/08/2020.

$\mathrm{Ba}$, Oumar, "This tiny African country got the U.N.'s top court to investigate Myanmar for genocide", The Washington Post, 29 Januar 2020, https://www.washingtonpost.com/politics/2020/01/29/this-tinyafrican-country-got-uns-top-court-investigate-myanmar-genocide/.

Beech, Hannah and Nang, Saw, "He Incited Massacre, but Insulting Aung San Suu Kyi Was the Last Straw", The New York Times, 29 May 2019, https://www.nytimes.com/2019/05/29/world/asia/myanmarwirathu-monk-buddhism.html.

Bo, Marta, "Crimes against the Rohingya: ICC Jurisdiction, Universal Jurisdiction in Argentina, and the Principle of Complementarity", http:/ /opiniojuris.org/2019/12/23/crimes-against-the-rohingya-iccjurisdiction-universal-jurisdiction-in-argentina-and-the-principle-ofcomplementarity/, 07/08/2020.

Burma Citizenship Law," 15 October 1982, dostupno na https://www. refworld.org/docid/3ae6b4f71b.html, datum pristupa 06/08/2020.

Cagape Wendell, Glenn P., "Finding Foucault in the Rohingya Discourses", Aseannale, Capturing the spirit of Asean in the Digital Time, 2018.

Constitution of the Republic of the Union of Myanmar.

174 Convention on Prevention and Punishment of Crime of Genocide. 
Deutsch, Anthony and Sterling, Toby, "Myanmar updates U.N. court on 'confidential' Rohingya measures", Reuters, 25 Maj 2020, https://www. reuters.com/article/us-myanmar-rohingya-world-court/myanmar updates-u-n-court-on-confidential-rohingya-measures-idUSKBN231124.

Douglas, Irvin-Erickson, Raphael Lemkin and the Concept of Genocide, University of Pennsylvania Press, 2017.

Dunant, Ben, "It's good to be Tatmadaw", The Diplomat, 11 May 2017, https:/ / thediplomat.com/2017/05/its-good-to-be-the-tatmadaw/.

Fumagalli, Matteo, "Myanmar 2019: The lady and the generaux" in Asia in 2019: Escalating international tensions and authoritarian involution, Michelguglielmo Torri, Nicola Mocci and Filippo Boni (eds), Asia Maior, The Journal of the Italian Think Tank, 2020, Viella s.r.l. \& Associazione Asia Maior, pp. 311-327.

Guensberg, Carol, "A voice for Justice for Rohingyas, Rwandas and Gambians", Voice of America News, 27 Maj 2020, https://www.voa news.com/africa/voice-justice-rohingyas-rwandans-and-gambians.

Human Rights Watch, "All of my body was pain: Sexual Violence against Rohingya Women and Girls in Burma", 16 November 2017, https:// www.hrw.org/report/2017/11/16/all-my-body-was-pain/sexualviolence-against-rohingya-women-and-girls-burma.

Hunt, Louise, "Gambia's genocide case against Myanmar shows that smaller countries can also help balance the scales of international justice", 27 Mart 2020, https:// www.equaltimes.org/gambia-s-genocide-case-against\#. Xy0bGSgzbIV.

Independent International Fact-Faction Mission on Myanmar, United Nations Human Rights Council, https:/ /www.ohchr.org/en/hrbodies/ $\mathrm{hrc} /$ myanmarffm/pages/index.aspx, 07/08/2020.

Independent Investigative Mechanism for Myanmar, https://www.ohchr. org/EN/HRBodies/HRC/IIMM/Pages/Index.aspx.

International Court of Justice, Application instituting proceedings and request for provisional measures, Republic of the Gambia v. Republic of the Union of Myanmar, 11 November 2019.

International Court of Justice, Application of the Convention on the Prevention and Punishment of the Crime of Genocide, Republic of the Gambia v. Republic of the Union of Myanmar, Order, 23 January 2020.

Knudson, Abigail, "The Rohingya Refugee Crisis \& International Implications", 2020.

Maung Aung, Myoe, Building the Tatmadaw: Myanmar Armed Forces since 1948, Institute of Southeast Asian Studes, Singapore, 2009.

Paquette, Danielle, "Why a tiny African country is taking the Rohingya's case to the world court", The Washington Post, 12 Novembar 2019, 
https://www.washingtonpost.com/world/africa/why-a-tiny-africancountry-is-taking-the-rohingyas-case-to-the-world-court/2019/11/12/ f491d5a4-04cd-11ea-9118-25d6bd37dfb1_story.html\#commentswrapper.

Parker, Edward, "What is the Future of the Media in Myanmar?", The Diplomat, 11 September 2017, https:/ / thediplomat.com/2017/09/whatis-the-future-of-the-media-in-myanmar/.

Pillai, Priya, "The Gambia v Myanmar at the International Court of Justice: Points of Interest in the Application", 21/11/2019, https://opionio juris.org/2019/11/13/the-gambia-v-myanmar-at-the-internationalcourt-of-justice-points-of-interest-in-the-application/.

Pyun, Jiuen, "Myanmar Must End Its Internet Shutdown", The Diplomat, 15 Jul 2020, https://thediplomat.com/2020/07/myanmar-must-end-itsinternet-shutdown/.

Rahman, Ziaur, Anusara, Jhensanam, Chanthamith, Bousaone, Hossain, Saddam, Amin, Al, "Rohingya crisis: identity of Rohingya Muslim in Myanmar", International Research Journal of Social Sciences, Vol 7, 2018, pp. 12-16.

Renshaw, Catherine, "Myanmar's Transition without Justice", Journal of Current Southeast Asian Affairs, 2019.

Report of the independent international fact-finding mission on Myanmar, Human Rights Council, Septembar 2019, https://documents-ddsny.un.org/doc/UNDOC/GEN/G19/236/74/PDF/G1923674.pdf?Ope nElement.

Rist, D. Wes, "What does the ICJ decision on The Gambia v. Myanmar mean?", https://www.asil.org/insights/volume/24/issue/2/whatdoes-icj-decision-gambia-v-myanmar-mean.

Ross, Aaron, "With memories of Rwanda: The Gambian minister taking on Suu Kyi", Reuters, 5 Decembar 2019, https://www.reuters.com/ article/us-myanmar-rohingya-world-court-gambia/with-memories-ofrwanda-the-gambian-minister-taking-on-suu-kyi-idUSKBN1Y91HA.

Schabas, William A., "Convention on Prevention and Punishment of the Crime of Genocide", Audiovisual Library on International Law, dostupno na: https:/ / legal.un.org/avl/ha/cppcg/cppcg.html, datum pristupa 21/08/2020.

Sumon, Shehab, "Ashin Wirathu: The Buddhist bin Laden", Arab News, 21 Avgust 2019, https://www.arabnews.com/node/1532846/world.

Truth, Reconciliation and Reparation Commission, http://www.trrc.gm/, 07/08/2020.

Universal Jurisdiction, International Justice Resource Center, dostupno na https://ijrcenter.org/cases-before-national-courts/domestic-exercise-ofuniversal-jurisdiction/, datum pristupa 21/08/2020. 
As a crime of special gravity and significance, genocide rightfully causes particular attention and caution in legal life. When it comes to its prosecution in international law, the International Court of Justice (ICJ) is the only relevant address, and genocide occupies a special place in the practice of the ICJ. Precisely because of that, the authors will analyze the progress achieved before the ICJ in the case of Myanmar, but at the same time, they will present the basic aspects of the concept of genocide and especially the specifics of the case, which shed special light on the whole process.

Keywords: Myanmar, the Gambia, Rohingya Muslims, genocide, International Court of Justice. 